\title{
Arbetarmobiliseringen i Ryssland från slutet av I980-talet till i dag
}

\section{Carine Clément}

SAMMANDRAG: Genom att fokusera på utvecklingen av arbetarrörelsen tar sig Carine Cléments artikel an tesen att postsovjetiska ryska medborgare skulle vara passiva och inte visa något stöd för demokratiska värderingar eller arbeta för social rättvisa. Utifrån ett omfattande empiriskt material, som sträcker sig från sent I980-tal till de senaste åren, beskriver denna studie förutsättningarna för och utmaningarna mot arbetarnas självorganisering i Ryssland. Clément demonstrerar att arbetskonflikterna i Ryssland tenderar att öka i antal under högkonjunkturer och minska i tider av ekonomisk kris. Den senaste lågkonjunkturen har inte lett till lika omfattande mobilisering som under krisen på 1990-talet. Formerna för organiserat motstånd mot marknadens orättvisor och ojämlikhet, och deras bakomliggande faktorer, har förändrats dramatiskt på tjugo år. När arbetskonflikter bryter ut påverkar de en mycket bredare social kontext och skapar nya former av solidaritet, men arbetarrörelsen i Ryssland har ändå inte mäktat frambringa beständiga mobiliseringsstrukturer som kunnat utmana de övergripande socioekonomiska hierarkierna.

NYCKELORD: Ryssland; arbetarrörelse; arbetare; arbetskonflikter; fackföreningar; strejker; social mobilisering.

PUBLICERINGSHISTORIK: Originalpublicering.

CARINe CLÉment är sociolog och docent vid Sankt Petersburgs statliga universitet. E-POSTADRESs: k.m.klement@spbu.ru

FÖRSLAG PÅ KÄLLANGIVELSE:

Clément, Carine (2017) "Arbetarmobiliseringen i Ryssland från slutet av I980-talet till i dag", i Från perestrojka till Bolotnaja. Utvecklingen av ett ryskt civilsambälle, specialnummer av Arkiv. Tidskrift för sambällsanalys, nr 7, s. 57-92.

DOI: https://doi.org/IO.I3068/2000-6217.7.2

(C) Carine Clément/Arkiv förlag \& tidskrift 2017 (publicerad 8 februari 20I7)

Artikeln distribueras enligt en upphovsrättslicens från Creative Commons: Erkännande-Ickekommersiell-IngaBearbetningar 3.0 Unported, som medger fri ickekommersiell användning och spridning i oförändrat skick så länge källan anges. 
Arkiv. Tidskrift för samhällsanalys är en sakkunniggranskad vetenskaplig tidskrift för samhällsvetenskap och historia. Samtliga artiklar publiceras fritt tillgängliga på:

$$
\text { www.tidskriftenarkiv.se }
$$

Beständig länk, DOI: https://doi.org/IO.13068/2000-62I7

Den här artikeln finns tillgänglig i följande format:

PDF \& HTML: via beständig länk, DOI: https://doi.org/IO.I3068/2000-62I7.7.2 EPUB: ingår i e-boksutgåva av numret, ISBN: 978917924283 I TRYCK: ingår i bokutgåva av numret, ISBN: 978 9I 79242848

Grafisk utformning och sidnumrering är identisk i pdf och tryck.

Samtliga artiklar i nr 7 (2017), Från perestrojka till Bolotnaja. Utvecklingen av ett ryskt civilsamhälle, nås via beständig länk, DoI: https://doi.org/IO.I3068/2000-6217.7

REDAKTÖR FÖR NUMRET: Zhanna Kravchenko

Arkiv. Tidskrift för samhällsanalys ISSN: 2000-62I7 (för elektronisk resurs) ISSN: 2000-6225 (för tryckta nummer)

ges ut av

Stiftelsen Arkiv för främjande och spridning av samhällsvetenskaplig och historisk forskning

genom

Arkiv förlag \& tidskrift

Box 1559

SE-22I OI Lund

ВESÖK: L Gråbrödersg 3 c, ipg

TEL: 046-I3 3920

ARKIV FÖRLAG: arkiv@arkiv.nu·www.arkiv.nu

TIDSKRIFTEN ARKIV: red@tidskriftenarkiv.se · www.tidskriftenarkiv.se

ANSVARIg UTGIVARE \& CHEFREDAKTÖR: Sven Hort

ADMinistrativ RedAKTÖr: David Lindberg ReDAKTörer: Paavo Bergman, Lisa Kings, Zhanna Kravchenko 


\title{
Arbetarmobiliseringen i Ryssland från slutet av 1980-talet till i dag
}

\author{
CARINE CLÉMENT
}

Det finns i dag en spridd föreställning om att "vanliga" medborgare i det postsovjetiska Ryssland snarast är passiva, inte särskilt demokratiska och benägna att stödja den "starka makten" (Mersijanova \& Korneeva 20II; Vinogradova m.fl. 20I2; Gudkov m.f. 2008). Tidigare undersökningar har förklarat den ryska politiska kulturens apolitiska karaktär med den långa historien av tsaristisk autokrati och sovjetisk totalitarism (Colton \& McFaul 2002), men också med de djupa socioekonomiska problemen med övergången till marknadsekonomi, den exempellösa sänkningen av levnadsnivån och det sociala förfallet "som lämnade praktiskt taget alla familjer med erfarenheter av livsmedels- och varubrist, obetalda löner, ekonomisk förnedring och statusförlust” (Judah 20I3, s. I3). Nödvändigheten att demonstrera sin lojalitet till makten i de samhälleliga organisationernas och föreningarnas arbete och samtidigt undgå statlig kontroll, vardagslivets utmaningar, men också påverkan från den nyliberala konsumtionsideologin, har sammantaget lett till att befolkningen förlorat sina orienteringspunkter, till svårigheter att begripa det nya samhället och sin plats i det och möjligheterna till aktiv medverkan. Som ett resultat av "marknadstsunamin" har detta lett till en stigmatisering av kroppsarbetarna, de fattiga och av alla dem som har visat sig oförmögna att anpassa sig till marknaden (Burawoy 20ı3), och därmed också demobiliserat den sociala proteströrelsen.

En allmän uppfattning är att den ryska befolkningen bara två gånger har visat prov på förmåga till social mobilisering och protest under senare 
år: under perestrojkan, när massprotestmöten och demonstrationer ledde till ett regimskifte, och under 20II-20I2, när de "uppretade stadsborna", särskilt i Moskva och Sankt Petersburg, gick ut på gatorna för att kräva rättvisa val. Denna bild är korrekt bara om vi uteslutande koncentrerar vår uppmärksamhet till opinionsundersökningar eller undersökningar av den "liberala Moskvaintelligentians” åsikter. Därför måste vi påminna om några övergripande trender i de sociala rörelsernas utveckling i det postsovjetiska Ryssland. Särskild uppmärksamhet förtjänar utvecklingen av fackförenings- och arbetarrörelsen som växte fram med en egen dynamik och inte sällan förenades med andra sociala rörelser. Just arbetarrörelsen spelade en ledande roll i sovjetregimens undergång i slutet av I980- och början av 1990-talet, men är i dag en av de svagare sociala rörelserna och har inte deltagit i den senaste mobiliseringsvågen. Denna artikel undersöker huvudlinjerna i fackförenings- och arbetarrörelsens utveckling från slutet av I980-talet och fram till i dag med syfte att förklara villkoren och hindren för dess framväxt, liksom orsakerna till att den nu har gått tillbaka.

\section{Det sociala uppsvinget I989-199I}

I slutet av 1980-talet inleddes den sociala mobiliseringen i och med signalerna om det statliga kontrollsystemets försvagning och gläntandet på det frihetsutrymme i vilket genast ett otal folkliga initiativ och rörelser stormade in och snabbt utvidgade fältet för det som var möjligt. Gräsrötterna i form av en omfattande föreningsstruktur (såväl officiella, som illegala och informella) var redan beredd (Šubin 1997). Härdarna för missnöje och kritik bara väntade på de gnistor som skulle sätta dem i brand. Trots den kontroll som parti- och statsapparat utövade på fackorganisationerna, ägde dessutom konflikter mellan makten och befolkningen rum även under sovjetperioden (jfr särskilt Kozlov 1999), och dessa visade att även sovjetsamhället fann en väg att tillförsäkra sig en nisch för självständigt handlande och tyst motstånd mot auktoritarismen, ända fram tills den illegala oppositionen skapades (Chauvier 1990; Lewin 2005; Šubin 2008).

Perioden I986-I988 präglades av att den så kallade informella rörelsen (Berezovskij \& Krotov I990; Fadin I990; Janickij I99I; Jušenkov I99I; 
Kagarlickij 1990; Šubin 2006) blomstrade och trädde ut i offentligheten. Denna rörelses rötter utgick från den inofficiella ungdomssubkulturen som uppstod i Sovjetunionen under 1960-talet och - i förändrad skepnad och under myndigheternas förföljelser - på 1970-talet gav upphov till rörelser med olikartade inriktningar och handlingsmetoder. Ur denna miljö kom även de första demonstranterna som stödde perestrojkan och demokratiseringen. I rörelsen korsades så olikartade rörelser som miljörörelsen - naturskyddsförbund, Bajkalrörelsen, initiativ mot byggandet av kärnkraftverk, miljöskyddskommittéer (Janickij 1996; Muchačev \& Zabelin 1992), pedagogikrörelsen (kommunary), rockmusikrörelsen, rörelsen för restaurering av ryska fornminnesmärken (Pamjat), för upprättandet av en minnesvård över Stalinrepressionens offer (Memorial), intellektuella klubbar och diskussionsklubbar. Och dessa omvandlades snart till politiska grupper. Något senare dök regionala folkfronter och nationalistiska rörelser upp - i sovjetrepublikerna, men också i regionerna (samlade kring krav på självbestämmande, kampen mot centraliseringen och ett försvar av de nationella eller regionala särdragen). På initiativ eller med stöd av myndigheterna (i form av kooperativ, arbetskollektivråd, kamratsällskap och kommittéer för socialt självstyre) såg denna tid en febril utveckling av självstyrelseinitiativ inom i huvudsak tillverkningssektorn, men också i bostadssektorn (Pickvance 1994). Inom den informella miljön rasade upphetsade diskussioner och intensiva åsiktsutbyten om det pågåendes natur, under vilkas inflytande många av de "informella” började politiseras (för detaljer, se Šubin i detta nummer).

I slutet av 1980- och början av 1990-talet antog de kollektiva handlingarna olika former, alltifrån gatuperformanceverk (Gladarev 20II) och deltagande i val, till demonstrationer och för samtidshistorien väldiga strejker (Gordon \& Klopov 1990; Levčik 2003), vilka inleddes på kolfälten (varifrån de fick benämningen "gruvarbetarrörelsen") och reste rent ekonomiska krav, som dock snabbt även utvidgades till politiska (arbetarkontroll, självstyre, upphävande av partiets ledande roll). Då uppkom också de första fria fackförbunden, i synnerhet Gruvarbetarnas oberoende fackförbund (Nezavisimyj profsojuz gornjakov, NPG). Vid den tid då gruvarbetarrörelsen var som störst, uttalade sig strejkkommittéerna och fackförbunden offentligt för demokratin och marknaden. 
Detta skedde i mångt och mycket under inflytande av de liberala reformistdemokraterna. Det var i synnerhet Jeltsin, Javlinskij och Gajdar som gick de strejkande gruvarbetarna till mötes och agiterade för reformer (Šablinskij 1995).

Vid denna tid betraktade många forskare gruvarbetarrörelsens utveckling med normativa och ideologiska ögon. För anhängarna av marknaden och Jeltsinreformerna borde arbetarrörelsen ha vuxit ut till en fackföreningsrörelse med syfte att tillsammans med nya ägare reglera marknaden. Huvudrollen i detta skulle spelas av en "arbetarelit", vilken skulle vara "demokratisk" och "sammansmält med marknaden", till skillnad från den konservativa massan av arbetare (Gordon 1995; Gordon m.fl. I993b). Marxistiska forskare ansåg tvärtemot att rörelsen borde växa ut till en rörelse för klassmotsättning (Rakitskaja 1993), särskilt efter att "chockterapin" hade förverkligats och arbetarna kunde känna av marknadsverkligheten in på bara huden. Då stötte man inte särskilt ofta på den mer ideologineutrala och mångsidiga analys som med tiden skulle bli möjlig. Några forskare noterade likväl den motsägelsefulla karaktären på arbetarrörelsens utveckling, dess vaga föreställningar om demokrati och marknad, dess splittring och dess begränsade solidaritet och organisatoriska svaghet (Clarke m.fl. 1993; Iljin 1998; Jadov 1998; Kaceva \& Patrušev 1994). Det var just korsningen och den kumulativa effekten av alla dessa orosvågor - arbetarnas, de informellas och nationalisternas - som, med medverkan av en del av nomenklaturan, ledde till sovjetsystemets sammanbrott, till Gorbatjovs avsättande och Jeltsins makttillträde. Denna period av demokratisk eufori och allas förening mot det kommunistiska enpartisystemet slutade med att Jeltsin valdes till president för RSFSR (den ryska sovjetrepubliken) i juni I99ı. De olika proteströrelsernas förbund hade egentligen börjat falla sönder tidigare, de olika ideologiska inriktningarna etablerade sig redan kring 1990. Men appellerna till massornas nödvändiga stöd för "reformlägret" mot "det konservativa lägret" fick överhanden och Jeltsin blev en symbol för demokratin och de marknadsliberala reformerna.

Under perioden 1989-1991 kom det tydliga signaler om att kontrollen från maktens sida försvagades (dessa uppfattades därtill entydigt av ett stort antal av de initiativtagande människorna), det fanns omfattande föreningsstrukturer (delvis nedärvda från sovjetperioden, delvis 
skapade på initiativ av perestrojkamakten); och splittringen av makten i ett demokratiskt och ett konservativt läger bidrog till att en del av maktkretsarna fick stöd från demonstranterna. Denna första våg av den kollektiva och offentliga proteströrelsen hade formen av självbefrielse och självbekräftelse, en akt syftande till att övervinna rädsla och demonstrera mänsklig värdighet. Dessutom fick den positiva uppfattningen om gatu- eller strejkdemonstrationerna vid spridning inte minst tack vare den "glasnost" som då rådde inom den demokratiska press vilken var på väg att utvecklas.

Vi kan vidare konstatera att mobiliseringen under perestrojkan hade en tydlig elitistisk karaktär. Intelligentian utgjorde en överväldigande del av demokratiaktivisterna under perioden: då aktiverades författare, publicister, vetenskapsmän, högkvalificerade yrkesmän, studenter. Några sociologer har till och med tolkat strejkrörelsen som ett verk av "arbetareliten" (Gordon m.fl. 1993a). Men det var just dessa aktörer (ur "eliten") som först av alla lämnade gatorna och produktionen och trädde in i den professionella politiken och därefter även i affärslivet. Tillsammans med den del av den sovjetiska nomenklaturan som gick segrande ur maktkampen, blev intelligentian och de nya entreprenörerna den nya härskande eliten, och de började lägga sig vinn om att befästa sin "demokratiska" makt mot "hotet om att vrida klockan tillbaka". I allmänhet skedde det nu en drastisk förändring i synen på och i tonen av rapportering i ledande massmedier och i politikernas och de makten närstående intellektuellas offentliga uttalanden om demonstrationerna och de medborgerliga massaktionerna. Demonstranterna och de protesterande började personifiera de reaktionära krafterna, och i revanschismen mot "det rödbruna hotet" genljöd uppmaningarna att stödja Jeltsin, "den enda garanten mot kaos och extremism". Ledarna för den demokratiska rörelsen förändrade dessutom, försåvitt de kom till makten, drastiskt diskursen. Folket visade sig, enligt mångas åsikt, ”inte vara redo för demokrati" på grund av sin "pöbelmentalitet" och "massornas okunskap". Och demonstrationerna och strejkerna blev synonyma med ansvarslöshet, fara och efterblivenhet. ${ }^{\mathrm{I}}$

I. Intervjuer med ledarna och politikerna i det demokratiska lägret (gjorda i april I994). Från en fältstudie jag gjorde om gatudemonstrationerna i Moskva 1987-1994 (Clément 2000). 


\section{Oppositionella framträdanden och socialt stillestånd} I992-I993

Med början I99I och särskilt under åren 1992-1993 erövrar de kommunistiskt och nationalistiskt inriktade oppositionella rörelserna gatorna åt "demokraterna" (men långt ifrån åt demokratin, åtminstone inte i bokstavlig bemärkelse). Under de här åren var de demonstrationer som organiserades av dessa grupper långt mer massorienterade än demokraternas tidigare demonstrationer. Man måste dock påpeka att dessa mobiliseringar snarare hade en politisk än en social karaktär. Demonstrationerna organiserades av de nya politiska organisationer som dök upp just då. De kommunistiska ståndpunkterna företräddes särskilt av "Det arbetande Ryssland" (Trudovaja Rossija), "Arbetarnas enhetsfront" (Objedinennyj front trudjaščichsja), "Ryska kommunistiska arbetarpartiet” (Rossijskaja kommunističeskaja rabočaja partija), Komsomolorganisationer ${ }^{2}$, vänsterpolitiska ungdomsgrupper och senare SUKP (fr.o.m. februari 1993), och de nationalistiska ståndpunkterna av "Rysk nationell enighet" (Russkoje nacionalnoje jedinstvo) och "Nationella räddningsfronten" (Front nacional'nogo spasenija).

Detta bör man dröja vid eftersom just akten att erövra "demokratin" åt de nykläckta "demokraterna” blev det allra mest väsentliga i den påföljande avvecklingen av det "demokratisk lägrets" aktivitet. I själva verket hade flertalet av dem som krävde "demokrati" på gatorna, i gruvorna och i valen en ytterst närliggande föreställning om det konkreta innehållet i detta begrepp. I början associerades "demokrati” med sådana slagord som "ge folket makten åter", "ner med byråkratin", "all makt åt råden”. På initiativ av de demokratiska liberalerna fogades därefter även krav på marknadsreformer till dessa slagord. Vid denna tidpunkt betydde marknaden för många social rättvisa (anständig lön, avskaffande av nomenklaturans privilegier, rättvis fördelning, garanti om sociala rättigheter), ekonomisk tillväxt och allmänt välstånd (som i det mytologiska väst). Fram till Sovjetunionens fall hyste de informella demokratiförkämparna allvarliga tvivel angående inriktningen på den rörelse som de själva var delaktiga i,

2. Kommunistitjeskij sojuz molodjozji ("Ungdomens kommunistunion"), ungdomsförbund för Sovjetunionens kommunistiska parti. Red. anm. 
de började också tvivla på troheten mot demokratin hos dem som kallade sig "demokrater" (Sokolov 1993). Allteftersom en inte försumbar del av ledarna började ingå i den nya makten (bland dumaledamöterna, i kabinetten, expertgrupperna) (Berelowitch \& Wieviorka 1996), blev rörelsen allt svagare. Och när demokrati- och marknadsreformerna började förverkligas, började också demokratirörelsen som social rörelse slutgiltigt stanna av, eftersom befolkningen började känna av konsekvenserna av I992 års "chockterapi”. Beskjutningen av Vita huset (parlamentsbyggnaden i Moskva) i oktober 1993 försatte de informella i ett sant och djupt chocktillstånd. De som fortsatte sin samhälleliga aktivitet efter dessa händelser befann sig i opposition till makten och kapitalet. ${ }^{3}$

Rörelsernas politiska karaktär innebar inte att aktivister med en social agenda saknades inom dem, men oppositionens huvudled utgjordes av politiska aktivister vilka vägleddes av ideologiska motiv och kampen om makten. Som helhet var den tidens oppositionsrörelse utesluten från de sociala föreningsstrukturerna och initiativen. Arbetarrörelsen hade vid det laget fallit samman, de nya fackföreningarna (med undantag för det lilla fackförbundet "Arbetets beskydd" (Zaščita truda)) stödde "reformlägret", och de gamla fackförbunden (vars ledning snarast stod i opposition mot reformerna) var inte i stånd till någon självständig massmobilisering. Det fanns nästan inga större arbetskonflikter, lejonparten av arbetarna intog en avvaktande hållning (de väntade på att kunna dra nytta av de första frukterna av reformerna och välkomnade "folkprivatiseringarna"). Undantag utgjordes av de så kallade direktörsstrejkerna (strejker som initierats av de "sovjetiska" direktörerna för att bibehålla stödet från statens sida eller mot försöken från de nya ägarnas sida att ta över företagen), de offentliganställdas protester, som organiserats av den gamla fackförbundsfederationen FNPR (Federacija nazavisimych profsojuzov Rossii, "Rysslands oberoende fackförbunds federation"), och några kategoriska strejker av arbetarfackföreningsmän, vilka hade organiserats av de "alternativa" fackförbunden (flygklarerarnas, järnvägsarbetarnas etc.). Andra sociala initiativ (intellektuella studiecirklar, miljöförbund,

3. Intervjuer med den första vågens informella demokratiförkämpar (obščestvennye) (gjorda i april 1994). Från fältstudien om gatudemonstrationerna i Moskva 1987-1994 (Clément 2000). 
bostadsföreningar) blev, om de inte helt upphört att existera, antingen inneslutna i de nya maktstrukturerna (expertgrupperna blev fler, liksom kommittéerna i duman och regeringen) eller förvandlades till ideella föreningar och började uppbära understöd från utländska fonder, eller till affärsstrukturer (Henderson 2002; Henry 2006).

\section{Den politiska aktivitetens nedgång och vitaliseringen av arbetarrörelsen I994-I998}

Från 1994 till 1998 förekom samhällelig protestaktivitet endast inom produktionssfären. Mängden strejker och arbetskonflikter växte successivt och dessa antog emellanåt häftiga former såsom vägblockeringar, övertagande av företag och gisslantagande av direktörer, men än mer ofta den desperata formen av hungerstrejk. Folk tog till kollektiva handlingar med två huvudmål: för att få sina innestående löner utbetalade och för att rädda företaget från konkurs. Aktiviteten inom denna sfär var förknippad med den allmänna ekonomiska och politiska situationen. Arbetarna började känna av följderna av de ekonomiska reformerna - för dem blev de synonyma med omfattande löneutbetalningsstopp, utarmning, "rövarekonomi", utförsäljning av produktionsegendomen och finansiellt fiffel. Och eftersom makten antingen inte ingrep eller själv var delaktig i denna situation (i egenskap av arbetsgivare åt de offentliganställda eller oligarkins handgångna män), blev protestframträdandena efter hand alltmer politiserade.

Den mest uppseendeväckande tilldragelsen under denna period blev det så kallade rälskriget, med mångdubblade fall av blockerade järnvägslinjer. Man minns särskilt gruvarbetarnas ständiga strejkvakt framför Vita huset under våren och sommaren 1998. Men samtidigt restes tältläger i många andra städer, längs Transsibiriska järnvägen i Sibirien, i Jaroslavl, i Astrachan och så vidare, vilka organiserades av strejkrörelsens koordinationsråd. I dessa läger deltog en vid krets av olika fackföreningsorganisationer (såväl nya som traditionella), spontant uppkomna strejkkommittéer eller arbetarkommittéer från olika företag, men också politiska organisationer på vänsterflanken. Deltagandet begränsades inte till gruvarbetarna utan omfattade företrädare för de mest skiftande 
yrken, i synnerhet arbetare inom fordonsindustrin och förädlingsindustrin, men också lärare och andra offentliganställda. Det var en massprotest mot den pågående monopoliseringen, svindlarnas och oligarkernas ekonomiska system (man hörde upprörda deklarationer mot "djungelkapitalismen", de "oligarkiska" och "folkfientliga" privatiseringarna, det finansiella fifflet, bolagsägarnas bedrägerier) och en uppmaning till myndigheterna att införa ordning och få ett stopp på "utförsäljningen av det nationella välståndet”.

Till dessa strejker och gatuprotester vill jag lägga de mer lokala, men till gensvaret omfattande, strävandena för att etablera arbetarkontroll på företagen. Efter att ha tröttnat på att iaktta hur produktionskapaciteterna på deras fabriker plundrades, vidtog arbetarna åtgärder (särskilt under 1997-1998) för att ta kontroll över utrustningen och produktionen, och ibland också över ledningen i sin helhet. I samband härmed kan man anföra exemplen Rostselmaš (Rostov-na-Donu), Jasnogorsks maskindustriella fabrik (i Tula län), Tutaevs motorfabrik (Jaroslavls län) och Viborgs pappersbruk (Leningrads län) där arbetarna generellt etablerade fullt självstyre. Dessutom fortsatte experimenten med arbetarkontroll i några månader och gav till en början, ända tills ägarna inledde sin blockad och sitt motangrepp, resultat: tillverkningen återupptogs och lönerna betalades ut. Försöken krossades av ekonomiska svårigheter, blockader från ägarnas sida och återupptagna strider om kontrollen. I fallet med pappersbruket i Viborg avbröts det av en beväpnad stormning av den fabrik som bevakades av arbetarna.

I sin helhet bör man förstås inte överdriva uppsvinget för arbetarrörelsen under de här åren. För det första var flertalet konflikter rent defensiva: för att ägarna inte skulle stänga fabriken eller för att lönerna skulle betalas ut. De reste inte frågan om löneförhöjning eller förbättrade arbetsvillkor. För det andra var rörelsens organisationsgrund, trots utvecklingen av en del koordinationsstrukturer, tämligen svag; flertalet konflikter var lokala, och uppmaningarna till arbetarsolidaritet fick ett svagt gensvar. Det har skrivits mycket om orsakerna till passiviteten under denna period (Clément 2000; Jadov 1998; Kabalina 1997; Klopov I995; Maksimov 1998; Zaslavskaja 2002): social destabilisering (oro för morgondagen), splittring ("var och en för sig" i relation till chefen), svag 
tilltro till fackförbunden, svag inbördes solidaritet, de utvecklade klientelistiska eller paternalistiska relationerna till ledningen, förkärleken för informella och individuella metoder att ta (eller "slingra") sig ur problem med appeller till formella regler och lagstadgade rättigheter.

$\AA$ andra sidan skapade den allmänna politiska och ekonomiska kontexten gynnsamma förhållanden för en proteströrelse. Det var i synnerhet kapitalismens skamlösa roffarkaraktär och Jeltsinadministrationens demonstrativa förbund med oligarkerna som framkallade ett enormt missnöje, vilket kunde utmynna i en kollektiv protest i närvaro av en handlingskraftig organisation och i en konkret hotsituation för företaget eller filialen. Därtill stod denna dominerande ideologi, som uppfattades som en uppmuntran till laglöshet och berikning med alla medel, i bjärt kontrast till värderingarna hos de arbetare som hade blivit lidande av svårigheterna. Maktens legitimitetskris nådde då sina högsta höjder (Rakitskij 1997; Rakitskij \& Rakitskaja 2000; Rudyk m.fl. 2000). Men arbetarna var likväl långt ifrån en social rörelse och hade ännu längre till en revolution. Den huvudsakliga anledningen var att de just då minst av allt såg sig själva som subjekt i kollektiva aktioner. I slutet av 1990-talet beskrev jag de ryska arbetarna som underkastade en kraftfull process av "avsubjektifiering" eller berövande en del av sig själva (med Marx termer skulle man kunna tala om alienering) (Clément 2000). I intervjuer med arbetare vid denna tidpunkt beskrev de antingen sig själva som ”överflödiga" eller som fullständigt beroende varelser. Det förekom även mer positiva individuella omdömen: "jag är människa med stor bokstav". Men positiva värderingar av arbetarna som samhällsgrupp var ytterst sällsynta (om man över huvud taget vidgick att en sådan grupp existerade). Större delen av arbetarkollektivet sjönk alltså ner i ett tillstånd av passivitet, och alla led passivt var för sig, som om de skämdes över sin egen belägenhet. Marken under deras fötter hade ryckts undan: man fick ingenting betalt för sitt arbete, man fick inget samhälleligt erkännande. Trots att de inte alls stämde överens med deras vardagserfarenhet, slog myterna om den fria övermänniskan och det individuella självförverkligandet raskt rot i deras medvetande. Och för många arbetare omvandlades det till en känsla av mindervärdighet och till oförmåga att engagera sig i proteströrelsen (jfr Ashwin 1998; Ost 2006). 
Huvudrollen i avsubjektifieringsprocessen spelades av de ledande massmedierna, politikerna och de intellektuella, vilka med en särskild iver spred negativa föreställningar om arbetarna. Olika medier framställde arbetarna som oduglingar, sovjetnostalgiker, missnöjda med allt och ständigt protesterande i stället för att arbeta (Clément 2000). Exempelvis skrev den kända sociologen och chefen för Det allryska centret för opinionsunderökningar Jurij Levada 1997 att "de huvudsakliga bärarna av 'proteststämningarna' i dagens läge utgörs av de som är allra minst progressiva, de skikt och grupper av befolkningen som är allra minst involverade i förändringsprocesserna", därför är all deras längtan "snarare vänd mot det förflutna än mot framtiden - mot en allmän statslivegenskap" (Levada 1997). Dessutom vill jag anmärka att den yttrandefrihet som så många intellektuella, liberaler och journalister i dag klagar på att de fråntagits, faktiskt var begränsad till just denna personkrets. Under 1990-talet hade arbetarorganisationerna inte tillgång till massmedias kanaler, vilket är begripligt eftersom de tillhörde de oligarker som arbetarrörelsen uttalade sig emot. Här är några artikelrubriker i samband med den allryska protestaktionen den 27 mars 1997: "Kommer protestaktionerna att övergå i masskravaller?" (Nezavisimaja Gazeta, 27 mars 1997); "Blir våren -97 början på en ny allmän sammandrabbning?" (Moskovskije Novosti, 23-30 mars 1997); "En tredje olycka drabbar Ryssland: dårarna visar vägen" (kommentar till ett fotografi från demonstrationen, Segodnja, 28 mars 1997). Finanskrisen i augusti 1998, det därpå följande regeringsskiftet, därefter Jeltsins frivilliga avgång och en viss återupplivning av produktionen satte hur som helst stopp för rörelsen. De krav arbetarrörelsen ställde I998 blev i mycket liten utsträckning tillmötesgångna. Samtidigt kan man anta att det var just som ett resultat av denna rörelse som ett skifte ägde rum i maktens diskurs. Införandet av ordning, kampen mot oligarkin, utbetalandet av de innestående lönerna, betonandet av produktion och återupprättandet av statens kontroll över ekonomin blev refrängen för Putinadministrationens första mandatperiod. Detta får vi inte glömma bort när vi analyserar orsakerna till Putins popularitet. 


\section{Ned- och uppgångar för aktivistpotentialen 1999-2008}

Med Vladimir Putins makttillträde falnade aktiviteten drastiskt. Alla indikatorer på samhällelig och politisk aktivitet gick raskt ner, och det skedde dessutom inom alla sfärer på en gång. Detta kan förklaras av den ekonomiska, sociala och politiska stabiliseringen. Produktionen återupptogs, den ekonomiska tillväxten fick fart, lönerna utbetalades i tid - allt detta gjorde människor mindre missnöjda med sin belägenhet. Genom att spela på patriotiska och antioligarkiska stämningar, på behovet av ordning och stabilitet, på en strävan efter social rättvisa, lyckades den nya makten skapa en bild som svarade mot befolkningens förväntningar. Det skedde förändringar i den officiella ideologin, särskilt i folkflertalets värdering av den: man fick intrycket att makten inte längre uppmuntrade till laglöshet och berikning med alla medel, som det hade varit under Jeltsin. Det ideologiska skiftet genomfördes med en reform av maktstrukturen som var inriktad på att stärka "vertikalerna", inom såväl politiken, ekonomin som samhällssfären (jfr Rodin 2006).

Som en följd av produktionsökningen och den avstannade kampen om egendom, men också av att den nya arbetsrättslagen antogs (30 december 200I), så stärktes arbetsgivarnas ställning på företagen. Till detta måste man också lägga den tillfredsställelse som följde av de regelbundna löneutbetalningarna och av höjandet av produktionsarbetets värde. Allt detta försvagade fackförbundens ställning, särskilt som

4. Föreliggande del av artikeln utgör en bearbetad version av ett kapitel som tidigare publicerats i Clément med flera (20IO). Uppgifterna insamlades av ett forskar- och samhällsaktörskollektiv som samarbetade med Institutet för kollektivt handlande (Institut kollektivnogo dejstija, IKD), en samhällsvetenskaplig icke-regeringsbunden organisation som från 2004 till 2012 bedrev en aktiv verksamhet som i första hand var inriktad på att stödja människors gräsrotsaktivism (IKD 20I5). Under alla dessa år och tack vare en mängd till hälften aktivistiska och till hälften vetenskapliga exkursioner runtom i landet samlades en enorm datamängd in: fler än 250 djupintervjuer med samhälleliga och fackföreningsbundna aktivister på alla nivåer, aktivisternas anteckningar, dagböcker över iakttagelser och fältstudier, fallstudier av de enskilda initiativgrupperna, av stads- och regionbundna och allryska rörelser och aktivistnätverk, men också anteckningar från informella samtal med aktivister och icke-aktivister. Resultaten av analysen och bearbetningarna av dessa data återfinns i hög grad i två verk som publicerats under ledning av mig (Clément 20I3; Clément m.fl. 20IO). 
den största - men också mest trögrörliga - fackförbundsorganisationen FNPR under loppet av diskussionen om förändring av arbetslagstiftningen fick ett kvasi-monopol på att företräda lönearbetarna i utbyte mot sin lojalitet.

Hela denna rad av reformer stärkte maktens kontroll över det samhälleliga och politiska livet. Och bland dessa reformer och deras konsekvenser bör man nämna stärkandet av de byråkratiska och formella hindren för demonstrationer och strejker, avskaffandet av direkta guvernörsval, att det blev praktiskt taget omöjligt att genomföra folkomröstningar på befolkningens initiativ, avskaffandet av kandidater från enmansvalkretsar i de allnationella parlamentsvalen, en höjning av spärren för partier att komma in i duman från 5 till 7 procent, svåruppfyllda kriterier för att registrera partier (minst 50 ooo medlemmar i 45 regioner), stärkande av statens kontroll över ideella föreningar (i synnerhet deras skyldighet att redovisa sin verksamhet för staten) och så vidare. Som ett resultat av detta krympte det offentliga rummet - som inte kunde begränsas till maktsfären - drastiskt. Det institutionella politiska systemet stängdes för nya aktörer, oppositionella, gräsrotsgrupper och grupper bortom maktens kontroll. Tack vare de direkta repressionerna och manipulationer av de administrativa resurserna så tillintetgjorde Putinstyret de facto den politiska oppositionen, vilken hade kunnat tjäna som en referenspunkt för de sociala rörelserna (March 2009; Robertson 2009).

Dessutom har maktens retorik förändrats med avseende på den sociala rättvisan, trots att innehållet i statens politik som tidigare håller sig till de nyliberala principerna (Cook 2007). Det är särskilt anslående i reaktionerna på massdemonstrationerna mot den "folkfientliga" monetariseringen av de sociala förmånerna: i Putinadministrationens diskurs började den populistiskt nationalistiska tonen för den statliga omsorgen om människorna och en kritik av "chockterapin" bli allt tydligare och som ett resultat av detta kan man kalla den innevarande regimens politik för en "sovjetisk nyliberalism" (Hemment 2009). Samtidigt fortsätter den liberaldemokratiska oppositionen hålla fast vid retoriken och värderingarna från 1990-talet och tilldelar dem som framträder med slagord om social rättvisa epitet som "paternalister", "auktoritära", "mer intresserade av materialistiska ting än av demokrati och kulturella eller moraliska 
värden" (Gudkov 20I2; Gudkov m.fl. 2008). Denna nedlåtande diskurs om "vanligt folk" i regionerna från Moskvaintelligentians sida fortsatte under de massiva protesterna för fria och rättvisa val under perioden 20II20I3. Situationen har av några kommentatorer beskrivits som ett "kulturellt krig" mellan "två Ryssland" (Matveev 20I4), vilket kan förklara det svala intresset för de demokratiska protesterna i Moskva bland "vanliga människor" i regionerna (Judah 2013), och särskilt bland arbetarna.

Putins andra presidentperiod (2004-2008) utmärktes av de mest omfattande arbetarprotesterna i det postsovjetiska Ryssland och blev en period av omfattande social gräsrotsaktivering. En av orsakerna till den nya mobiliseringsvågen var den relativa ekonomiska stabilitet som hade skapats fram till denna stund och i att man ställdes inför hot om nya reformer som skulle beröra den sociala sektorn och den samhälleliga tjänstesektorn. Från slutet av 2004 genomfördes det ena efter det andra framträdandet mot vad man kallade "monetariseringen av de sociala förmånerna” i form av massprotestmöten och demonstrationer, övertaganden av statliga institutioner och blockeringar av vägar i ett tiotal städer (särskilt i Sankt Petersburg, Moskvaområdet, Izjevsk, Perm, Barnaul, Omsk, Kurgan, Saratov, Tver, Blagovesjtjensk, Novosibirsk, Samara). De som först gick ut på gatorna var människor utan aktivisterfarenhet, de var inte politiserade och tillhörde inte något av de politiska partierna, och de satte igång utvecklingen av, för det postsovjetiska Ryssland, nya former av rörelser som skapats underifrån på initiativ av medborgarna själva. På så vis uppkom rörelsen mot bebyggelseförtätning, rörelsen för "lurade andelsägare", studentboenderörelsen, rörelsen för de boendes kontroll över kommunala tjänster och bostadstjänster, minibusstaxichaufförernas rörelse, motormännens rörelse, gatuförsäljarnas rörelse och så vidare.

2007 inleddes en ny våg av strejker och arbetskonflikter som vi ska dröja mer i detalj vid längre fram. Vi påminner om att man från I997 till 1998 nådde en kulmen av kollektiva aktioner, som utmärktes av sådana företeelser som "rälskriget" och långvariga experiment med arbetarkontroll över produktionen. Finanskrisen i augusti 1998 och den efterföljande uppgången inom produktionssektorn ledde till en drastisk nedgång i proteststämningarna hos arbetarna, som med lättnad kunde 
koncentrera sina ansträngningar på att tjäna pengar. Makten reagerade omedelbart på den nya situationen. Genom regeringens och ledamöterna från Enade Rysslands ansträngningar antogs i december 200I den nya arbetsrättslagen, som flerfaldigt sänkte nivån på arbetstryggheten för alla kategorier av lönearbetare och ökade handlingsfriheten för arbetsgivarna. Dessutom blev den nya lagen ett vapen i kampen mot de "obekväma" fria fackförbunden och den fråntog praktiskt taget arbetarna strejkrätten (se även Clarke 2005). Under loppet av fem år kämpade de fria fackförbunden förgäves mot detta regeringsprojekt. Och den officiella fackförbundsunionen FNPR övergav utan att blinka lönearbetarnas ståndpunkt i utbyte mot att den näst intill tillförsäkrades monopol på fackförbundsområdet. Så inträdde ett stillestånd i de fria fackförbundens utveckling, även om de lyckades överleva och anpassa sig till de nya förutsättningarna. Som en följd av alla dessa faktorer gick antalet arbetskonflikter ner drastiskt. Enligt uppgifter från Rosstat (Ryska federala statliga statistikbyrån) minskade antalet strejker ständigt från år 2000 (de symboliska endagsstrejker som utbildningsväsendets fackförbund organiserade 2004-2005 kan knappast räknas som fullvärdiga strejker) och ända till 2006 när de officiellt registrerade strejkerna endast var åtta. Men efter det fullständiga avbrottet i början av 200o-talet, framträdde, med början 2006, en tydlig tendens till en pånyttfödelse för de kollektiva arbetskonflikterna (Kozina 2009).

För att förstå de sociala och arbetsmässiga förhållandena är det nödvändigt att ta avstamp i arvet från det förflutna och de allmänna politiska och ekonomiska villkoren i Ryssland, som snarast skapar hinder på vägen mot utvecklingen av arbetarrörelsen och förklarar dess relativa svaghet (i jämförelse med, exempelvis, länderna i Väst- och till och med Östeuropa). Huvudhindret utgörs av existensen av ett flertal fackförbund som endast är fackförbund till namnet. Paradoxalt nog har Ryssland en av de högsta fackliga organisationsgraderna i världen (formellt är 50 procent av lönearbetarna organiserade). Däremot deltar arbetarna i realiteten lite i den fackliga verksamheten och det är inte heller vanligt att de försöker påverka fackförbundsledningarna att aktivera sig. Merparten av de ryska fackförbunden ingår i den ovan nämnda FNPR som formellt företräder 45 procent av lönearbetarna och 90 procent av fackförbunds- 
medlemmarna. Här måste man förtydliga att det inte går att tala om denna gigantiska struktur i sin helhet. Enskilda fackförbundsgrenar (särskilt gruvarbetar-, jordbruksnärings-, varvsarbetar- och lärarförbundet) utmärks av en relativt högre aktivitetsgrad och principfasthet. Enskilda lokala fackklubbar kan ibland under trycket av de egna medlemmarnas proteststämningar ta till arbetskonflikter för att försvara arbetarnas intressen. Men federationsledningens huvudsakliga linje och ståndpunkt (särskilt så länge den befann sig under Michail Šmakovs ledning) har handlat om lojalitet i förhållande till såväl arbetsgivarna som myndigheterna. Man behöver bara nämna att FNPR ställde upp i de federala valen I995 tillsammans med industriidkarnas och företagarnas förbund under den talande samlingsbeteckningen: blocket "Rysslands fackförbund och företagare - Arbetets förbund". Om fackförbundsfederationens verkliga inflytande vittnar även indirekt blockets resultat: I,55 procent. Sedan dess har FNPR alltid deltagit i maktpartiets listor och har därför sina företrädare i statsduman och även i Enade Rysslands ledningsorgan (den mest namnkunniga av dem är Andrej Isaev, den förste vicesekreteraren för partirådets presidium och viceordförande för FNPR).

De "alternativa" eller "fria" fackförbunden har visat sig vara mer aktiva och självständiga från arbetsgivarna. Från och med slutet av 2006 inleddes en ny fas i deras tillkomsthistoria. De fria fackförbunden förblev svaga och i minoritet men stärkte likväl sina ställningar, särskilt efter att de 20 Io enats till "Rysslands arbetskonfederation" (Konfederacija truda Rossii, KTR), som blev en samlingspunkt för alla "stridande" fackförbund vilka ansåg sig själva självständiga från såväl arbetsgivare som staten. De som ingick i den nya sammanslutningen var: Flygklarerarnas fackförbundsfederation (FPAD), Fordonsindustriarbetarnas interregionala fackförbund (MPRA), Ryska stuveriarbetarförbundet, Sjöfartsarbetarnas fackförbund, "Arbetets beskydd" (Zaščita truda), Filmindustrioch televisionsarbetarnas förbund, Lotsförbundet, Fackförbundet för järnvägsarbetarnas lokomotivsektion, Små och medelstora företags förbund "Rättvisa" (Spradelivost'), Fackförbundet "Läraren" (Učitel'), Sjukvårdsarbetarförbundet "Handling" (Deistvie).

De fria fackförbunden har sin bas i den mest aktiva delen av lönearbetarnas egenorganisering. De kämpar för att höja lönen, ingå normala 
kollektivavtal och erhålla normala arbetsvillkor. Dessa fackförbund tilllåter inte företrädare för företagets administration och ledning att bli medlemmar. Och, åtminstone där de är starka (flygklarerarna, stuveriarbetarna, maskinbyggnads- och bilindustrin), så omformar de arbetarnas syn på vad ett fackförbund är.

Huvudhindret på de fria fackförbundens utvecklingsväg är de begränsade resurserna (de lever huvudsakligen på medlemsavgifterna), bristen på politisk betydelse (de företräds av ett litet fătal politiker och de försök som gjorts för att skapa ett eget politiskt parti har misslyckats) och en otillräcklig närvaro i offentligheten. Man måste också peka på arvet från sovjetsystemet som vant av arbetarna vid att kämpa för sina rättigheter, diskrediteringen av den kollektiva solidaritetens värderingar och tradition, förlusterna av tidigare sociala tryggheter och den repressiva statsapparaten. Om de fria fackförbunden, som höll fast vid demokratiska synsätt, på 1990-talet åtnjöt om inte stöd så åtminstone frihet från inblandning från statsmaktens sida, började de på 2000-talet utsättas för påtryckningar från de statliga maktorganen. Den nya arbetsrättslagen var uppenbarligen skapad mot dem.

\section{Uppgången för arbetar- och fackföreningsrörelsen 2007-2008}

Som påpekats ovan så framträdde, efter det fullständiga stilleståndet i början av 2000-talet, från slutet av 2006 en tydlig tendens mot en pånyttfödelse av kollektiva arbetskonflikter, vilken liknade den som iakttagits i slutet av 1980- och i början av 1990-talet, men nu med en annan innebörd och ett annat innehåll. Det ska genast anmärkas att den officiella statistiken inte alls speglar dynamiken i uppgången för strejkrörelsen. För 2007 registrerades allt som allt sju strejker och för 2008 totalt fyra. Det beror på att den statliga statistiken bara tar hänsyn till "lagliga” strejker, men eftersom det med antagandet av den nya arbetsrättslagen blev nästan omöjligt att genomföra en laglig strejk, så existerade praktiskt taget inte heller några "statistiska" strejker. 2007 genomfördes, enligt uppgifter från Institutet för kollektivt handlande (IKD), åtminstone 35 strejker. Under 2008 genomfördes, enligt uppgifter från IKD och 
Centret för sociala och arbetsrelaterade rättigheter, I06 arbetskonflikter - varav 53 var strejker.

Den första och en av de mest omtalade händelserna 2007 blev den utdragna strejken på den ryska Fordfabriken i staden Vsevolozjsk i Leningrads län. Jag vill påminna om att arbetarna inledningsvis försökte lösa konflikten med fredliga medel. I många månader ignorerade fabriksadministrationen fackförbundets krav på ett nytt kollektivavtal vilket framför allt rörde sig om förbättrade arbetsförhållanden. Den gick med på förhandlingar först efter att arbetarna i handling, genom en strejk, hade visat att de var i stånd att försvara sina rättigheter. Det räckte med ett dygns strejk den I4 februari 2007 för att administrationen skulle gå med på att göra eftergifter. Icke desto mindre blev kraven på höjda löner (med omkring 30 procent) inte tillmötesgångna. Denna punkt infördes i protokollet över meningsskiljaktigheter och förhandlingarna och försoningsprocedurerna pågick oavbrutet under de påföljande månaderna. När förhandlingarna inte ledde någonstans, tvingades fackförbundet att föreslå arbetarkollektivet att återuppta strejken. Förslaget antogs av en överväldigande majoritet av lönearbetarna på ett stormöte. Detta resulterade i att omkring I 500 arbetare (allt som allt arbetade 2000 personer på fabriken) lade ner arbetet under nästan ett dygn den 7 november. Man tvingades dock avbryta strejken efter ett domstolsbeslut. Den utländska arbetsgivaren använde sig av den väg som blivit de ryska kollegornas älsklingsväg - att vända sig till domstol med anledning av strejkens olaglighet. Men på Fordfabriken hade fackförbundet enat det stora flertalet av arbetarna och blivit ett verkligt verktyg för arbetarnas egenorganisation och till försvar för deras rättigheter. Därför visade det sig förmöget att iaktta alla de oräkneliga lagkraven för genomförande av strejk och, inte desto mindre viktigt, i stånd att samla nästan alla arbetare kring det utstakade målet och vägen mot detta måls förverkligande. Den 20 november inleddes därför, under fullt iakttagande av alla de formella procedurerna, på nytt en strejk, som nu skulle pågå i nästan en månad. Detta möjliggjordes tack vare de möten som deltagarna i strejken och fackföreningsmedlemmarna höll varje dag. Man gjorde då kollektivt upp planer, man planerade för protestmöten och strejkvakter och diskuterade förhandlingstaktiken. Det demokratiska tillvägagångssättet med de stän- 
diga kontakterna mellan fackförbundets aktivister borgade, kort sagt, för en enad motståndsfront, som arbetsgivaren på inget vis kunde bryta varken genom att hyra in strejkbrytare, eller genom hot och löften, eller genom desinformation.

Men ledningen föredrog i det längsta att bära enorma förluster på grund av strejken framför att höja lönen och erkänna att arbetarna kunde åstadkomma det minsta lilla med strejkmetoden. I slutändan besegrades de strejkande av fattigdomen - man kunde inte längre kompensera löneförlusterna med strejkfonden, trots det finansiella stöd som man i och utanför Ryssland visade arbetarkollektivet. Fabriksadministrationen gjorde en del eftergifter - man gick bland annat med på att höja lönerna med I6-2I procent (mot kravet på 30 procent) - och genom en omröstning beslutade en majoritet av arbetarna att anta administrationens bud. Man bör här särskilt peka på den demokratiska procedur som fackförbundsledarna använde sig av för att lösa konflikten. De organiserade inte bara en omröstning, utan också en hemlig omröstning. En sådan taktik tillämpas mycket sällan av fackförbund, eller över huvud taget av samhälleliga organisationer. Fackklubben på Ford visade sin handlingsduglighet, demokratiska karaktär, förhandlingsförmåga och sammanhållning. Det är också värt att notera att arbetsgivaren i efterspelet inte fullständigt vågade göra processen kort med fackförbundsledarna som de hade hotat avskeda. Huvudlärdomen från konflikten är att Fordarbetarna blev en symbol - för landet och världen - för fackförenings- och arbetarrörelsens pånyttfödelse i Ryssland. Exemplet med själva Fordstrejken, men också fackförbundsledarnas målinriktade ansträngningar för fortbildning och att upprätta kontakter ut i det omgivande samhället, kan i mångt och mycket förklara varför strejk- och fackföreningsrörelsen blev så aktiv i Sankt Petersburg och Leningrads län.

Under 2007 genomgick arbetarrörelsen flera djupa kvalitativa förändringar. Antalet konstruktiva kollektiva aktioner växte - det rörde sig inte längre bara om hungerstrejker (och/eller självmord), utan om egenorganiserade initiativ och aktioner som var grundade i medvetenheten om den egna värdigheten. Det är anmärkningsvärt att den nya strejkvågen omfattade en så pass vid krets av branscher och regioner. Man kan peka på den särskilda aktiviteten hos arbetarna på lönsamma företag, 
i första hand transnationella bolag som var fast integrerade i världsmarknaden (exempelvis strejken på den ryska Fordfabriken). Ett annat område för kollektiv aktivitet var de strategiska branscher som underhåller de centrala samhällsfunktionerna. Till dem kan man räkna postväsendet (i april 2007 strejkade det federala postväsendets fackförbund "Ryska postverket" i Sankt Petersburg), allmänna kommunikationer (i februari 2007 strejkade arbetarna i Astrachans eldrivna passagerartransportbolag, i april arbetarna på Perms läns förenade statsbolag "Busstation” i Perm, i augusti förarna och konduktörerna på de privata bussarna i Tiumen), utvinnings- och förädlingsbranscherna (hösten 2006 strejkade oljearbetarna i det autonoma distriktet Chanty-Mansijsk, gruvarbetarna på ön Sachalin, metallarbetarna på företaget "Karelens järnmalmspellets", som ingick i stålbolaget Severstal), kommunala bygg-, drifts- och underhållsbolag (hösten 2007 i Sverdlovsks län, den medicinska personalen i Kaliningrad) bland flera exempel.

Bland huvuddragen i arbetarnas proteströrelse 2007 kan man också peka på nya former av nätverkssolidaritet, höjda förväntningar hos lönearbetarna och arbetskonflikternas offensiva karaktär (inte bara för att lönerna skulle utbetalas, utan också för att de skulle höjas, samt för förbättrade arbetsvillkor), och skapandet av horisontella förbindelser mellan fackföreningsorganisationerna, några politiska grupper (som regel med vänsterinriktning och partipolitiskt obundna) och några samhälleliga organisationer. I Sankt Petersburg agerade sålunda framgångsrikt "Kommittén för solidariska aktioner", en icke-officiell sammanslutning av fackföreningar och politiska aktivister, vilka gav sitt verksamma stöd till de fackföreningar som initierade de kollektiva aktionerna. Dessutom kan man peka på utvecklingen av internationella kontakter mellan arbetarna i Ryssland och utländska arbetare i transnationella sammanslutningar och mobiliseringen av de unga och de högkvalificerade arbetarna, vilka var rustade att stå emot de informella och lagstridiga praktikerna på de företag som var befriade från den traditionella paternalistiska kulturen.

Nästan alla de påföljande strejkerna - med undantag för de "krisstrejker" som hade formen av vägran att utföra obetalt arbete - förklarades för olagliga eller erkändes över huvud taget inte som strejker. De följdes 
ofta av repressioner. Detta hindrade emellertid inte deltagarna från att i många fall få en del av sina krav tillgodosedda. Parallellt med strejkerna använde man sig aktivt av påtryckningsformer mot arbetsgivarna som "italiensk strejk" (maskning), gatudemonstrationer, hungerstrejker. Den allmänna opinionen började snarast sympatisera med strejkrörelsen, och även sociologkåren började nu höja sin röst inte bara till försvar för affärsintressena, utan också för lönearbetarnas intressen. Sociologiska massenkäter kan inte säga mycket om den verkliga proteströrelsen, men kan vittna om en attitydförändring i form av undertryckt missnöje med arbetsgivarna och (vilket var nytt) med myndigheterna. I en enkät som offentliggjordes i december 2008 och som hade genomförts av stiftelsen "Opinionen" (Fond "Obščestvennoe menenie") deklarerade 27 procent av de tillfrågade arbetarna att de var redo att delta i strejker, vilket utgör en toppnotering under de senaste åren (Fond "Obščestvennoe menenie" 2008).

Under 2008 fortsatte fackförenings- och arbetarrörelsen att utvecklas enligt de tendenslinjer som hade präglat 2007. Mot slutet av året slog finanskrisen till, vilket ledde till en förändring av aktionernas format och innehåll, men inte till att sakta ner arbetarnas aktiveringsgrad och fackförbundens pånyttfödelseprocess. Samtidigt intensifierades repressionen och förföljelserna av arbetaraktivisterna. Den sociala spänningen tilltog som en följd av såväl den ekonomiska krisen som arbetsgivarnas repressiva politik. Under året ägde, som vi redan nämnt, Io6 arbetskonflikter rum. Under det färrde kvartalet 2008 registrerades 40 arbetskonflikter. Det är betydligt fler än under det första (I7 konflikter), andra (19 konflikter) och till och med tredje kvartalet (30 konflikter). Bland årets alla konflikter var runt 27 strejker (oftast spontana), 40 gatudemonstrationer, I4 hungerstrejker och 26 individuella (men kollektivt organiserade) nedläggningar av arbetet. Under det fjärde kvartalet växte antalet protestmöten och övriga gatudemonstrationer samtidigt som antalet egentliga strejker sjönk, särskilt i jämförelse med det tredje kvartalet. Uppenbarligen tyckte arbetarna att gatudemonstrationer utanför fabriksmurarna var det bästa sättet att kämpa mot nedskärningar och för att bevara produktionen. Man kan anta att detta påverkades av krisen och det därtill kopplade hotet om att förlora arbetet. 
Om vi under de första nio månaderna 2008 såg ett växande antal strejker som dessutom, i kraft av sin fundamentala nyhet, delvis bar just den offensiva karaktär som karakteriserade protesterna 2007, så följde under det färde kvartalet i stället antingen gatuaktioner (protestmöten, strejkvakter, blockader av vägar etc.) eller nedläggningar av arbetet på grund av uteblivna löneutbetalningar. Det är värt att påminna om att det rör sig om paragraf I42 i Ryska federationens arbetsrättslag som ger, i fall när lön varit innestående under en längre period än Is dagar, arbetaren rätten att, efter att skriftligen ha informerat arbetsgivaren, lägga ner arbetet tills den innestående summan har utbetalats. Formellt räknas detta inte som strejk, därför kan arbetsgivarna inte ställa dem inför rätta för strejken. Det finns dock undantag: exempelvis stämde ledningen för det statliga företaget "Norra flottans örlogsbyggnadsstyrelse" (Voenno-morskoe stroitel'noe upravlenie Severnogo flota) företagets lokala fackklubb, som hjälpte folk att utforma individuella arbetsnedläggningar på grund av innestående lön. Domstolen avslog för övrigt stämningsansökan. Man bör särskilt understryka fackförbundens förstärkta roll i användandet av denna protestform. Fackförbunden, såväl de traditionella som de fria, började aktivt och framgångsrikt använda denna möjlighet att utöva påtryckning på arbetsgivare utan att genomföra någon formell strejk. De samordnade arbetarnas handlingar för att ett så stort antal arbetare som möjligt samtidigt skulle lägga ner arbetet - då var det möjligt att helt ställa in produktionen, och det blev svårare för arbetsgivaren att utöva påtryckningar på enskilda arbetare. Under krisens inledningsfas hittade fackförbund och arbetare en lämplig sorts "antikrisvariant" av arbetskonflikt. Men man måste anmärka att de kollektiva aktioner som var kopplade till krisen inte heller i detta format fick någon masskaraktär, och de omfattade inte heller alla företag som brottades med svårigheter.

Förutom kollektivt organiserade individuella arbetsnedläggningar, tog arbetarna (också med hjälp av fackförbunden) allt oftare till gatuaktioner med ett vitt spektrum av krav - huvudsakligen kopplade till att bevara företag och arbetstillfällen. Så långt det är möjligt att bedöma med utgångspunkt i befintliga data, så hade dessa protestmöten liten påverkan på arbetsgivarens neddragningsbeslut, men de kunde dra till 
sig allmänhetens och myndigheternas uppmärksamhet och därmed "bromsa upp" situationen. Det förekom några få fall av vägblockeringar eller "ockupationer" av direktörens kontor (på Ufas produktionsbolag för instrumentbyggnad inträffade sålunda den I2 november 2008 en strejk som hade formen av att Ioo kvinnliga arbetare från sektor 5 samtidigt kom till personlig mottagning hos direktören för det statliga flygföretaget), men de "mjuka" formerna av protestmöten och spontana sammankomster dominerade. Inga fastställda exempel finns på att arbetare tog över företagen som ett svar på fabriksplundringar, såsom skett i slutet av i990-talet.

Strejker och arbetskonflikter ägde inte bara rum i de stora städer som också var större industriella centrum, utan en betydande del av dem skedde även i små städer och samhällen, särskilt i brukssamhällena. Exempelvis hölls ett antal massprotestmöten med krav på att inte genomföra några personalnedskärningar och utbetala det innestående av lönerna på pappersbruket i Bajkal i oktober 2008. På ett möte som hölls den 20 december i Magnitogorsk, kopplat till massavskedanden på det metallurgiska industrikombinatet och höjda avgifter för kommunala bostadstjänster och resekostnader med allmänna färdmedel, samlades omkring I ooo personer, huvudsakligen pensionärer. Arbetarna på Pikalevskij cement $\mathrm{AB}$ (som ingår i Eurocement-gruppen) framträdde mot hotet om massuppsägningar på ett protestmöte den 8 november. Arbetarna och invånarna i Tulajev demonstrerade mot nedskärningar och flerfaldiga höjningar av avgifter från december 2008 till februari 2009. Den 2 november och 2 december hölls protestaktioner i samhället Petrovskij i Gavrilovo-Posadskoje-området i Ivanovo län. Arbetarna på den lokala spritfabriken krävde att de innestående lönerna skulle betalas ut och samhällets invånare att "tjänstemännens laglöshet" skulle stävjas.

De mest anslående strejkerna 2008 organiserades av fackförbunden - i första hand de "alternativa", exempelvis i gruvan "Rödluvan" (Krasnaja šapočka) i samverkan med Gruvarbetarnas oberoende fackförbund (NPG). I slutet av mars 2008 vägrade fler än hundra av gruvans arbetare att hissas upp ur gruvorten till ytan och reste en rad krav till gruvans ägare, däribland om löneförhöjningar på 50 procent. Därefter följde en hungerstrejk som avslutades den I8 april - efter att löftena vederbörligen 
hade uppfyllts. Arbetet återupptogs. Men vi ska än en gång upprepa att fackförbundens mest utbredda handlingsmetod blev att organisera hjälp för att utforma individuella arbetsnedläggningar på grund av innestående löner.

Arbetskonflikterna omfattade nästan alla sociala och professionella kategorier av arbetstagare (det enda undantaget var de lägre tjänstemännen, "kontorsråttorna", vilka också hade berörts av krisen). Om strejkrörelsens förtrupp 2007 hade utgjorts av högkvalificerade och relativt unga arbetare, så aktiverades, i och med krisens inledning och spridningen av en sådan protestform som protestmötet, alltmer äldre och lågkvalificerade arbetare, och till och med gästarbetare. Under 2008 har man kunnat fastställa några fall av spontana strejker som genomfördes av utländska byggnadsarbetare. Den mest uppseendeväckande av dem blev en aktion som genomfördes av de byggnadsgästarbetare som anordnade en tvåveckorsstrejk i Jekaterinburg från 27 november till 9 december. Fler än 300 byggnadsarbetare från Tadzjikistan, Uzbekistan och Kirgizistan, som höll på att bygga ett luxuöst bostadshus i stadens centrum, krävde att lönen för det utförda arbetet skulle betalas ut.

När de första tecknen på den ekonomiska krisen började visa sig i slutet av 2008 skärptes alltså fackföreningsaktivisternas påtryckningar som svar på arbetsgivarnas påbörjade nedskärningar av omkostnaderna för arbetskraften. De styrande kretsarna reagerade paniskt på den uppkomna situationen genom att skärpa lagstiftningen om extremism och högförräderi, genom att ta till våld för att skingra protestaktioner (motormannarörelsen i Vladivostok den 20 och den 2I december 2008) och genom att arrestera fackförbundsledare (den Io december arresterades ordföranden för det nya fackförbundet på Tenneco Automotive-Volga AB under förevändningen att han var "lik" en efterlyst brottsling).

\section{Motstånd trots påtryckning under 2009}

Som vi har sett bromsade inte den ekonomiska krisen upp utvecklingen av fackförenings- och arbetarrörelsen, utan förändrade bara dess karaktär - under denna period började de spontana och gatubaserade protestaktionerna för utbetalning av innestående lön få överhanden. I början av 
2009 bemötte arbetarna krisen förhållandevis passivt, men i maj-juni iakttogs en drastiskt tilltagande aktivitet, i första hand i form av gatudemonstrationer och mindre protestaktioner som gick utanför ramverken för lagstiftningen om lösandet av arbetskonflikter. Därpå följde en långsam men ihållande tillväxt av antalet arbetskonflikter, i första hand i form av protestmöten. Den tilltagagande spänningen tog sig också uttryck i icke-offentliga och ganska ofta individuella former (hungerstrejk, "italiensk strejk", ibland också självmord). År 2009 tilldrog sig enligt uppgifter från IKD I83 arbetskonflikter (i verkligheten var de sannolikt fler). Under första halvåret 2009 försiggick 67 konflikter, varvid nästan hälften av dem inträffade i maj-juni. Under det andra halvåret noterades II6 konfliktfall (hälften av dem var protestmöten). I jämförelse med 2007 avlöstes strejkerna alltså av gatuprotestmöten under denna period. Detta var en följd av krisen, vilken gjorde ett produktionsstopp till ett mer riskabelt vapen, liksom av begränsningar i arbetslagstiftningen, som gjorde strejker illegala.

Den mest anspända situationen kunde iakttas i brukssamhällena där stadens invånare i stället för arbetarna deltog i protestaktionerna. $\mathrm{Om}$ man ska tala om de branscher där konflikterna var mest utbredda bör man framför allt nämna bilindustrin, försvarsindustrierna, jordbruket och metallindustrin. Men som helhet ökade antalet konflikter inom praktiskt taget alla branscher. Så blev exempelvis staden Pikaljovo (Leningrads län) en symbol för den nya protestvågen, när stadens invånare den 2 juni 2009 blockerade trafiken på den federala vägsträckningen Sankt Petersburg-Vologda. Runt 300 arbetare på stadens företag och deras familjemedlemmar deltog i den spontana aktionen. Högljutt gensvar fick även en annan konflikt som till betydelse var jämförbar med den i Pikaljovo, eftersom de vanligtvis passiva läkarna och medicinska personalen nu för första gången gick ut på gatorna. Den 29 maj 2009 hölls i Archangelsk ett möte i vilket omkring 450 personer deltog: läkare från Archangelsk, Severodvinsk och Novodvinsk och specialister från länets regioner. Sjukvårdspersonalen krävde framför allt att länets kliniker skulle tillförsäkras den utrustning som är nödvändig för ett kvalitativt arbete, att villkoren skulle förbättras och lönerna höjas, samt att ett program skulle utarbetas för att komma till rätta med underskottet på personal i länets kliniker. 
Den 29 juni hölls strejkvakt på sjukhusområdet med understöd av läkare som hotades av disciplinära straff.

Konflikterna 2009 hade som helhet en defensiv karaktär, de offensiva handlingar som arbetarna iscensatte 2007-2008 inträffade sällan, även om dess potential som förut bevarades i form av arbetstvist och strejkhot initierade av fackförbunden. Under dessa krisomständigheter spillde arbetskonflikterna över på det omgivande samhället och antalet offentliga, spontana och demonstrationsliknande aktioner ökade drastiskt. Detta vittnar om att arbetskonflikterna inte kunde lösas på företagen, särskilt med tanke på den existerande arbetslagstiftningen. Arbetarna utvidgade sin arsenal av protesthandlingar och dessutom gick flertalet aktioner utanför ramarna för de former som lagen föreskrev för reglerande av arbetstvister. Det inträffade inte därför att människor strävade efter att bryta mot lagen, utan eftersom lagen var föga lämpad för att lösa sådana tvister.

Likväl förekom det offensiva protestaktioner när arbetarna inte bara gjorde motstånd mot en försämring av sin situation, utan också krävde att den faktiskt skulle förbättras. Sådana aktioner genomfördes antingen i form av spontana strejker eller i form av arbetsnedläggningar inom ramarna för en tvist som hade organiserats av fackförbunden. Med fackförbundens hjälp använde man sig också av metoden att maska ("italiensk strejk"). Den mest omtalade "italienska" strejken hölls på GM Autos fabrik i Sankt Petersburg från den II till 20 november 2009. På initiativ av Fordonsindustriarbetarnas interregionala fackförbund (MPRA) maskade en rad arbetare på svetssektionen så mycket de bara kunde den II november och satte igång en "italiensk" strejk. Fackförbundet krävde att man omedelbart sammankallade en konferens för fabrikens arbetskollektiv, avskaffade de årliga arbetspremierna och i stället garanterade årliga löneförhöjningar i nivå med inflationen plus 8 procent för varje arbetat år, tydliga regler för att reglera den årliga semestern, men framför allt en övergång från den summerade årsredovisningen till en normal fyrtio timmars arbetsvecka. Det är viktigt att notera att det inte bara var fackförbundsmedlemmar som deltog i strejken, utan också vanliga arbetare. Under några timmar lyckades till exempel lackeringssektionen helt och hållet stoppa det löpande bandet, men efter ”övertygande klar- 
göranden” från ledningen återupptogs arbetet. Produktionsmålet uppnåddes däremot inte. Fabriksadministrationen kändes offentligt inte vid någon som helst strejk, men den 20 november avskedade man den lokala ledaren för MPRA Jevgenij Ivanov med hjälp av en formulering om "arbetsskolk".

På grund av den oro som krisen framkallade, men också i förbindelse med att nya stridbara fackförbund dök upp och några traditionellt trögrörliga och lojala fackförbund aktiverades, grep sig företagsstyrelser och ägare nu an fackförbunden med fördubblad energi. En "fana" för kampanjen mot fackförbunden höjdes av Timur Gorjaev, generaldirektör för koncernen Kalina AB (Sverdlovsks län). I en intervju för internettidningen Delovoj kvartal ("Affärskvartalet") från 5 oktober 2009 deklarerade han öppet:

Fackförbunden har redan i flera år, som kackerlackor, som vägglöss, försökt tränga sig in på företagen med olika löjliga metoder, och det irriterar mig. För mig är de som en sekt. Om något slags blodsugarpedofiler och satansdyrkare spände upp sina klibbiga nät och började dra in jobbarkollektivet $\mathrm{i}$ dem, så skulle det nog vara mer begripligt för er varför jag knäpper dem på fingrarna. Och för mig är det lika avskyvärt att en sekt, att manipulatörer, strävar efter att förverkliga sina materiella och politiska mål på bekostnad av företaget. Det gör detsamma vilket.

De rättsvårdande myndigheterna inbjöd i sin tur fackförbundsledarna till "samtal" och försökte väcka åtal - oftast med anledning av någon ickesanktionerad protestaktion, ibland med anledning av någon fabricerad lagöverträdelse. Som exempel kan man peka på de försök som ett centrum för kamp mot "extremism" gjorde för att hitta tecken på just extremism i uppmaningar om att bilda lokala fackföreningar (exempelvis i de flygblad som MPRA delade ut på Centrosvarmaš AB i Tver). En annan metod blev att avskeda obekväma fackföreningsaktivister på fabricerade grunder. Några av de omtalade exemplen är avskedandet av fackordföranden Ivanov och den kvinnliga fackföreningsaktivisten Šafikovaja på GM Auto efter de "italienska strejker" som berörts ovan.

Men i sin helhet använde man sig framför allt av taktiken att söndra och härska. Under vintern 2008-2009 blåste man till exempel upp en historia om att bilarbetarna i Vladivostok skulle ägna sig åt en "under- 
grävande” verksamhet mot fosterlandets arbetare. Mot detta reagerade fackförbunden snarast med kamp för att bevara sitt oberoende och för rättning i leden. Så framträdde exempelvis fackföreningen på Ford på en solidaritetsaktion med uttalandet: "Petersburgs arbetare är inte fiender till arbetarna i Fjärran Östern”, varpå Sällskapet för Rysslands medborgarinitiativ (TIGR - en nätverksrörelse som hade uppstått i slutet av $2008 \mathrm{i}$ protestvågen mot tullavgifterna på importerade bilar) genmälde: "Fjärran Österns arbetare är inte fiender till arbetarna i Petersburg!" Och de fria fackförbunden tog initiativet till en sammanslagningsprocess som ledde fram till centralorganisationen "Rysslands arbetskonfederation" (KTR).

En positiv tendens i den spontana protestvågen för att rädda produktionen var inte desto mindre att det dök upp nya ledare för FNPR och att de lokala cellerna i FNPR aktiverades. Fackförbunden började slå tillbaka de försök som gjordes för att splittra deras led och för att frånta dem deras självständighet.

\section{En fortsatt tillväxt av arbetskonflikterna efter 2009}

I samband med den nya mobiliseringsetappen förknippad med "rörelsen för rättvisa val" eller "Bolotnajarörelsen", 5 men också som en följd av den skärpta repressionen och av den konservativa politiken, fortsatte mängden arbetskonflikter att växa med samma karakteristiska drag som hade varit utmärkande för 2009. Arbetsgivarna fortsatte, trots att den ekonomiska tillväxten kom igång på nytt fram till nästföljande kris i slutet av 20I4, att spara in på lönerna och genomförde en omstruktureringspolitik som gick ut på att dra ner på de fasta tjänsterna genom outsourcing, att införa resultatberoende arbetslön eller öka den rörliga delen av lönen och införa flexibel arbetstid och så vidare. Kort sagt det som i väst blivit känt under beteckningar som "flexibilitet", "prekarisering" och "informalisering". Flertalet arbetare har fogat sig i dessa företeelser utan motstånd, men allt fler ser en orättvisa i dem och försöker bekämpa dem genom kollektiva aktioner eller genom att gå samman i ett fackförbund.

5. Här undersöker jag inte denna rörelse eftersom den varken var någon gräsrots- eller arbetarrörelse, och eftersom den utvecklades separat från dessa, jämför Sachnins artikel i detta nummer för fler detaljer. 
Enligt uppgifter från Centret för sociala och arbetsrelaterade rättigheter inträffade det under 2010205 arbetskonflikter, under 20II: 263, 20I2: 285, 20I3: 278, och 20I4: 293 (Bizjukov 2015). Att döma av dynamiken under första halvan av 2015 så fördubblades antalet arbetskonflikter som en följd av den svåra ekonomiska krisen, vilken hade slagit hårt mot arbetarnas löner. Dessutom genomfördes allt fler konflikter i form av strejk. Huvudorsakerna till konflikterna var lönesänkningar eller förändringar av regler för löneberäkning, försämrade arbetsvillkor, hot om avsked och omstrukturering av företagen. Återigen fick innestående löner en allt större betydelse. En positiv tendens kan skönjas i att fackföreningar nu utvecklas också inom branscher där de tidigare i praktiken varit frånvarande eller overksamma, som inom IT-branschen eller på utbildnings- och sjukvårdsområdet. Samtidigt råder det fortfarande en övervikt för spontant uppkomna strejker, eftersom det saknas fackföreningar, och fackföreningarna är också fortsatt utsatta för repressioner.

För att förstå de ovan beskrivna tendenserna inom den nya mobiliseringsvågen 2005-2015, såväl inom arbetar- och fackföreningsrörelsen som andra proteströrelser, kan man notera de fundamentala skillnaderna i förhållande till det sociala uppsvinget 1989-199I. Den allmänna politiska kontexten hade naturligtvis radikalt förändrats. Under denna nya våg mobiliserade sig inte människor för att skynda på något slags reformer eller störta det rådande systemet. Hur vi än beskriver det, så gav det system som växt fram inte folk någon anledning att tro att det hade försvagats, man kan till och med säga att det tillfredsställde större delen av befolkningen. På det institutionella planet förblev det politiska systemet ytterst slutet för gräsrotsinitiativen; ett förbund slöts mellan eliter och byråkrater av alla politiska riktningar för att bevara systemet och sin plats i det. Medborgarinitiativen åstadkom inte förändring huvudsakligen genom direkt konfrontation med systemet, utan fann sina vägar genom att slå in på nya stigar för självhävdelse och motstånd.

Den andra skillnaden består i att den nuvarande aktiveringen inleddes under principiellt annorlunda stabilitetsförhållanden, såväl politiska som ekonomiska. Som Tatjana Vorožejkina (2008) påpekar är en stabil ekonomisk utveckling och inkomstökning för en betydande andel av befolkningen ojämförbart mer gynnsam för ett samhälles egenorganise- 
ring än en situation av djupaste ekonomiska kris och en sönderfallande statsmakt. En majoritet av befolkningen har fått mark under fötterna och behöver inte bara slita hårt och överleva, utan kan även ägna uppmärksamhet åt det som pågår omkring dem. Många har kunnat tillförsäkra sig en stabil ställning som tillåter dem att hämta andan och inte tvingar dem att varje dag kämpa för sin överlevnad. Folk vet mycket väl vilka ansträngningar detta blygsamma välstånd har kostat dem, och hämtar ur det just den känsla av självförtroende som arbetarna saknade när de kastades in den vilda kapitalismens storm under 1990-talet. De är inte redo att bli fråntagna det välstånd som de har uppnått med sitt arbete.

Den tredje skillnaden består i att de berömda konstnärer, högstatusintellektuella och kända journalister som I989-I99I utgjorde en inte obetydlig del av aktivisterna nu var ett betydligt mindre framträdande inslag. Vanliga människor, det så kallade folket, gjorde nu kort sagt anspråk på att spela rollen som aktiva och respekterade medborgare. På ett motsvarande sätt - och detta är den färde skillnaden - så skrev man betydligt mindre om dem, man visade dem inte på teve (om det inte handlade om något intressant skådespel $\mathrm{i}$ form av vägblockader eller andra spektakulära handlingar), man bjöd inte in dem till respekterade konferenser om Rysslands utvecklingsvägar. Oftast fäste man inte ens något avseende vid dem. Mediebelysningen av de sociala rörelserna och opinionsbildarnas förhållande till dem skilde sig med andra ord på ett fundamentalt sätt från hur man hade förhållit sig till den första vågen av medborgarmobilisering tjugo år tidigare. Och inte bara därför att offentligheten hade inskränkts intill censurens gräns eller på grund av just censuren, utan också för att medborgarinitiativen under denna period inte hade kopplingar till etablissemanget och saknade representanter från eliten bland sina led.

\section{Avslutning}

Dynamiken i utvecklingen av arbetarrörelsen och de sociala rörelserna visar att deras uppsving sammanfaller med perioder av relativ ekonomisk stabilitet, när folk kan tänka på annat än på att få vardagen att gå ihop. En kris bromsar tvärtom upp utvecklingen av den samhälleliga och 
fackliga aktiviteten. Likväl har inte kriserna 2008-2009 och 20I4-20I5 avspeglat sig lika starkt på rörelserna som det ekonomiska sammanbrottet gjorde under 1990-talet. Strejkerna blir visserligen färre och protestaktionerna får en mer defensiv karaktär, samtidigt lämnar arbetskonflikterna företagsområdena och tar plats i samhället så att antalet offentliga aktioner och demonstrationer ökar. Arbetarna drabbas återigen, som på I990-talet, av innestående löner, men regarerar nu allt oftare och mer operativt, utan att vänta på att skulderna ska hopa sig. Den nya generationens arbetare verkar mindre villiga att arbeta utan betalning mot löften om framtida lön, de känner bättre sitt arbetes värde.

Vi måste notera ytterligare ett viktigt karaktärsdrag i den nuvarande protestvågen: konflikterna utbryter oordnat och spontant, och de utmynnar inte i någon massbetonad och varaktig rörelse som skulle kunna vara i stånd att påverka den övergripande socioekonomiska färdriktningen. Än så länge står det klart att myndigheternas och företagens handlingar är inriktade på att ta sig ur krisen på bekostnad av arbetarna (genom lönesänkningar, nedskärningar, innestående löner) och inte till priset av en sänkning av de vinster, aktieutdelningar och bonusar som ägarna har sparat ihop till under perioden av ekonomisk tillväxt.

Någon övergripande arbetarrörelse skapas inte på grund av att konflikterna är strängt lokalt förankrade - koordinationsstrukturen och de horisontella banden mellan de som deltar i kampen saknas. För en massbaserad och ihållande rörelse krävs en organisationsstruktur, koordinationsorgan och en fackförbundssolidaritet, vilken arbetsgivarna och myndigheterna uppenbarligen hindrar genom att inrikta sig på att påverka och splittra fackförbunden. Splittringen förklaras också av att flertalet av de mest radikala konflikterna äger rum utan de fria fackförbundens vetskap, utanför deras nätverksstrukturer.

Men huvudorsaken till splittringen ligger i den svaga solidariteten. Arbetarna är ytterst individualiserade, de förhåller sig till arbete som till ett personligt värv och ser sig inte som en del av ett solidariskt kollektiv. De handlingskraftiga fria fackföreningarna är i stånd att bryta igenom en sådan hållning, men sådana är det ont om. Möjligen hade tendensen mot atomisering kunnat brytas av den allmänna upprördheten över det uppkomna förhållningssättet till lönearbetarna i det moderna Ryssland 
och en övergripande strävan efter social rättvisa. Men arbetserfarenheten uppfattas sällan i termer av rättvisa/orättvisa, utan långt oftare i termer av personliga förtjänster/förluster. Som vi sett ovan gör inte arbetarna någon koppling mellan det som inträffar på arbetsmarknaden och politiken. Arbetarna är ännu mindre benägna att se sina svårigheter som en konsekvens av kapitalismen eller nyliberalismen. Härav den dominerande slutsatsen: arbetar- och fackföreningsrörelsens huvudsakliga svaghet ser man i den svaga solidariteten inom den övergripande rörelsen, inklusive med de andra sociala initiativen och rörelserna, men också i frånvaron av politisk medvetenhet.

Det finns enskilda fall av samarbete mellan fackförbunden och de sociala rörelserna, men de är inte utbredda och är inte tillräckliga för att överbrygga isolering och den lokala förankringen. I vilken mån den spontana protestvågen kommer att mynna ut $\mathrm{i}$ en organiserad rörelse som är i stånd att frambringa reella åtgärder till skydd för arbetsrelaterade och sociala rättigheter beror på just fackförenings- och arbetarrörelsens ansträngningar. Det inger hopp att det nuvarande arbetskollektivet inte längre ser ut som på 1990-talet och att arbetarna inte i samma utsträckning kommer tolerera angrepp på sina rättigheter och intressen. De uppvisar en allt större förmåga till att organisera sig själva och försvara sina rättigheter. Det har vuxit fram en generation arbetare som har andra föreställningar om sin värdighet och anspråk. De kommer knappast att dra åt livremmen utan tungt vägande skäl och knappast "leva sig in" i de personers "situation" som vägrar avstå ifrån nästa jeep eller sommarstuga. Appellerna till patriotism kommer sannolikt inte heller länge lyckas fă människor att glömma sina dagliga problem.

\section{Översättning: Pontus Lindgren}

\section{Referenser}

Ashwin, S. (1998) "Endless patience: explaining Soviet and post-Soviet social stability", Communist and Post-Communist Studies, 31: 187-198. Dor: https://doi.org/Io.IoI6/So967-067X(98)00006-3

Berelowitch, A. och Wieviorka, M. (1996) Les russes d'en bas. Enquête sur la Russie postcommuniste, Paris: Seuil. 
Berezovskij, V. och Krotov, N. (1990) Neformal'naja Rossiia. O neformal'nich politizirovannych dviženijach $i$ gruppach RSFSR (opyt spravočnika), Moskva: Molodaja gvardija.

Bizjukov, P. (2015) Trudovye protesty v Rossii v 2008-20I4 gg., rapport från Centr social'notrudovych prav, 28 januari 2015 .

URL: http://trudprava.ru/expert/analytics/protestanalyt/1357 (27 augusti 2015)

Burawoy, M. (2013) "Ethnographic fallacies: reflections on labour studies in the era of market fundamentalism", Work, Employment \& Society, 27: 526-536.

DoI: https://doi.org/IO.II77/09500I70I2460316

Chauvier, J. M. (I990) URSS: une société en mouvement, Paris: Ed. del'Aube.

Clarke, S. (2005) "Post-socialist trade unions: China and Russia”, Industrial Relations Journal, 36: 2-I8. DOI: https://doi.org/IO.IIII/j.I468-2338.2005.00342.x

Clarke, S., Fairbrother, P., Burawoy, M. och Krotov, P. (1993) What about the workers? Workers and the transition to capitalism in Russia, London: Verso.

Clément, C. (2000) Les ouvriers russes dans la tourmente du marché, 1989-1999. Destruction d'un groupe social et remobilisations collectives, Paris: Syllepse.

Clément, C. (red.) (2013) Gorodskie dviženija Rossii v 2009-20I2 gg. Na puti kpolitičeskomu, Moskva: Novoe literaturnoe obozrenie.

Clément, C., Mirjasova, O. och Demidov, A. (2010) Ot obyvatelej k aktivistam. Zaroždajuščiesja dviženija v sovremennoj Rossii, Moskva: Tri kvadrata.

Colton, T. och McFaul, M. (2002) "Are Russians undemocratic?", Post-Soviet Affairs, I8: 9 I-I2I.

URL: http://www.tandfonline.com/doi/abs/I0.1080/1060586X.2002.I064I5I5 (3 november 2016)

Cook, L. J. (2007) Postcommunist welfare states. Reform politics in Russia and Eastern Europe, Ithaca: Cornell University Press.

Fadin, A. V. (I990) "'Neformaly i vlast'. Razmyšlenija o sud'bach graždanskogo obščestva v SSSR”, i E. A. Suslova (red.), Obščestvennye samodejatel'nye dviženija. Problemy $i$ perspektivy, Moskva: NII kul'tury.

Fond "Obščestvennoe menenie" (2008) "Rossijane o s'ezde 'Edinoj Rossii', zabastovkach i zakupke produktov vprok", från Polit.ru, I4 december 2008. URL: http://polit.ru/article/2008/I2/I4/fom4849/ (27 augusti 20I5)

Gladarev, B. (20II) "Istoriko-kul'turnoe nasledie Peterburga: roždenie obščestvennosti iz ducha goroda”, i O. Charchordin (red.), Ot obščestvennogo k publičnomu, Sankt Petersburg: Res Publica.

Gordon, L. (1995) "Social'no-trudovye issledovanija”, i Rabočee dviženie v segodnjašnej Rossii. Stanovlenie, sovremennye problemy, perspektivy, Moskva: Vyp. I, IMĖMO.

Gordon, L. och Klopov, Ė. (I990) "Perestrojka i novoe rabočee dviženie", i A. A. Protaščik (red.), Černii ternii, Moskva: Progress.

Gordon, L., Gruzdeva, E. och Komarovskij, V. (I993a) Šachtëry-2. Social'noe soznanie rabočej èlity, Moskva: Progress-kompleks.

Gordon, L., Klopov, E. och S̆ablinskij, I. G. (red.) (I993b) Na puti k social'nomu partnërstvu. Razvitie social’no-trudovych otnošenij v sovremennoj Rossii: ot odnostoronne- 
komandnogo upravlenija $k$ trëchstoronnemu sotrudničestvu, specialnummer av Konstitucionnyj Vestnik, $\mathrm{nr} 2$.

Gudkov, L. (20I2) "Social'nyj kapital i ideologičeskie orientacii", Pro et Contra, I6: 6-3I.

Gudkov, L., Dubin, B. och Zorkaja, N. (2008) Postsovetskij čelovek i graždanskij obščestvo, Moskva: Moskovskaja škola političeskich issledovanij.

Hemment, J. (2009) "Soviet-style neoliberalism? Nashi, youth voluntarism, and the restructuring of social welfare in Russia", Problems of Post-Communism, 56: 36-50. URL: http://www.tandfonline.com/doi/abs/ıo.2753/PPCio75-8216560604 (3 november 2016)

Henderson, S. (2002) "Selling civil society: Western aid and the nongovernmental organization sector in Russia", Comparative Political Studies, 35: 139-167. DOI: https://doi.org/IO.II77/00I04I400203500200I

Henry, L. A. (2006) "Shaping social activism in post-Soviet Russia: Leadership, organizational diversity and innovation", Post-Soviet Affairs, 22: 99-I24.

URL: http://www.tandfonline.com/doi/abs/ı0.2747/IO60-586X.22.2.99 (3 november 20I6)

IKD (20I5) Svodki protestnoj aktivnosti, Institut kollektivnogo dejstija. URL: http://www.ikd.ru/taxonomy/term/13 (27 augusti 20I5)

Iljin, V. I. (1998) Vlast' i ugol'. Šachterskoe dviženie Vorkuty (I989-1998 gody), Syktyvkar: Syktyvkarskij gosudarstvennyj universitet.

Jadov, V. A. (red.) (1998) Solidarizacija v rabočej srede. Social'noe i individual'noe, Moskva: Institut sociologii RAN.

Janickij, O. N. (I99I) Social'nye dviženija. Ioo intervju s liderami, Moskva: Moskovskij rabočij.

Janickij, O. N. (1996) Ekologičeskoe dviženie v Rossii. Kritičeskij analiz, Moskva: Institut sociologii RAN.

Judah, B. (2013) Fragile empire. How Russia fell in and out of love with Vladimir Putin, New Haven: Yale University Press.

Jušenkov, S. N. (199i) "Proščaj Gaid-park na Puškinskoj”, i S. Mitrochina (red.), Chronograf-go, Moskva: Moskovskij rabočij.

Kabalina, V. I. (red.) (1997) Predprijatie i rynok. Dinamika upravlenija i trudovych otnošenij v perechodnyj period, Moskva: ROSSPĖN.

Kaceva, A. M. och Patrušev, S. V. (1994) "Trudovye konflikty i zabastovki (oktjabr' 1993sentjabr' 1994)", Social'nye problemy, trudovye konflikty i rabochie organizacii v SNG, 5-6.

Kagarlickij, B. (1990) "Roždenie graždanskogo obščestva”, i E. A. Suslova (red.), Ob̌̌čestvennye samodejatel'nye dviženija. Problemy i perspektivy, Moskva: NII kul'tury.

Klopov, Ė. (1995) "Perechodnoe sostojanie rabočego dviženie", Sociologičeskij žurnal, I: IO-28.

Kozina, I. (2009) "Zabastovki v sovremennoj Rossii", Sociologičeskie issledovanija, 9: I3-24.

Kozlov, V. A. (1999) Massovye besporjadki v SSSR pri Chrusitjeve i Brežneve, Novosibirsk: Sibirskij Chronograf. 


\section{CLÉMENT | ARBETARMOBILISERINGEN I RYSSLAND}

Levada, J. (1997) "Massovyj protest: potencial i predely", Monitoring obščestvennogo mnenija, 3: 7-I2.

Levčik, D. A. (2003) "Zabastovočnoe dviženie šechtërov I988-I99I gg.", Sociologičeskie issledovanija, Io.

Lewin, M. (2005) The Soviet century, London: Verso.

Maksimov, B. (1998) Govorjat rabočie Kirovskogo zavoda, Moskva: Škola rabočej demokratii.

March, L. (2009) "Managing opposition in a hybrid regime: Just Russia and parastatal opposition", Slavic Review, 68: 504-527.

Matveev, I. (20I4) "The 'Two Russias' culture war: Constructions of the 'people' during the 20II-2013 protests", South Atlantic Quarterly, II3: I86-I95.

DOI: https://doi.org/IO.I215/00382876-2390482

Mersijanova, I. V. och Korneeva, I. E. (201I) Vovlečennost' naselenija v neformal'nye praktiki graždanskogo obščestva i dejatel'nost' NKO. Regional'noe izmerenie, Moskva: NIU V்̌̌́.

Muchačev, S. G. och Zabelin, S. I. (1992) 30 let dviženija. Neformal'noeprirodoochranitel'noe dviženie v SSSR. Fakty i dokumenty I960-1992, Moskva: Terra.

Ost, D. (2006) The defeat of solidarity. Anger and politics in postcommunist Europe, Ithaca: Cornell University Press.

Pickvance, C. G. (1994) "Housing privatization and housing protest in the transition from state socialism: a comparative study of Budapest and Moscow", International Journal of Urban and Regional Research, i8: 433-450. DoI: https://doi.org/IO.IIII/j.I468-2427.I994.tboo277.x

Rakitskaja, G. (I993) Na puti $k$ sobstvennoj ideologii (idejnye predstavlenija i trebovanija trudjaščichsja v chode četvertoj russkoj revoljucii), Moskva: IĖ RAN.

Rakitskij, B. (red.) (I997) Social’naja politika, social'naja zaščita, samozaščita trudjaščichsja $v$ obščestve, Moskva: Trudovaja demokratija ( $\mathrm{nr} 9)$.

Rakitskij, B. och Rakitskaja, G. (2000) Uroven' i perspektivt demokratičeskogo deistvija trudjašcichsja, Moskva: Trudovaja demokratija (nr 27).

Robertson, G. B. (2009) "Managing society: Protest, civil society, and regime in Putin's Russia", Slavic Review, 68: 528-547.

Rodin, J. (2006) Rethinking Russian federalism. The politics of intergovernmental relations and federal reforms at the turn of the Millenium, avhandling, Stockholm: Stockholms universitet.

Rudyk, E. N., Keremeckij, Y. N. och Bulavka, L. A. (2000) Rabočij protest v Rossii. Opyt i problemy, Moskva: Ékonomičeskaja demokratija.

Šablinskij, I. G. (I995) Rabočee dviženie i rossijskaja reforma, Moskva: Institut gosudarstva i prava RAN.

Sokolov, V. M. (1993) "Nravstvennye kollizii sovremennogo obščestva”, Sociologičeskie issledovanija, 9: 42-51.

Šubin, A. V. (1997) Istoki Perestrojki (1978-1984), Moskva: Institut ètnologii i antropologii.

Šubin, A. V. (2006) Predannaja demokratija. SSSR i neformaly 1986-1989, Moskva: Evropa.

Šubin, A. V. (2008) Dissidenty, neformaly i svoboda v SSSR, Moskva: Veče. 
Vinogradova, E., Kozina, I. och Cook, L. J. (2012) "Russian labor: Quiescence and conflict", Communist and Post-Communist Studies, 45: 219-23I.

DoI: https://doi.org/Io.IoI6/j.postcomstud.20I2.06.oII

Vorožejkina, T. (2008) "Samozaščita kak pervyj šag k solidarnosti", Pro et Contra, I2 $(2-3): 6-23$.

Zaslavskaja, T. (2002) "Nepravovye trudovye praktiki i social'nye transformacii v Rossii”, Sociologičeskie issledovanija, 6: 3-I7. 


\section{Anders Kjellberg Fackliga organisationer och medlemmar $i$ dagens Sverige}

Anders Kjellbergs numera klassiska undersökning av förändringarna i det svenska fackliga landskapet under 1980- och 1990-talet är fortfarande aktuell i sina frågeställningar och diskussioner om hur det fackliga arbetet kan förnyas för att möta en utveckling där fackligt medlemskap inte längre är en självklarhet och för att förhindra en tudelning av arbetsmarknaden i "vinnare" och "förlorare".

Arkiv förlag, andra utvidgade och reviderade upplagan 2001, $423 \mathrm{~s}$.

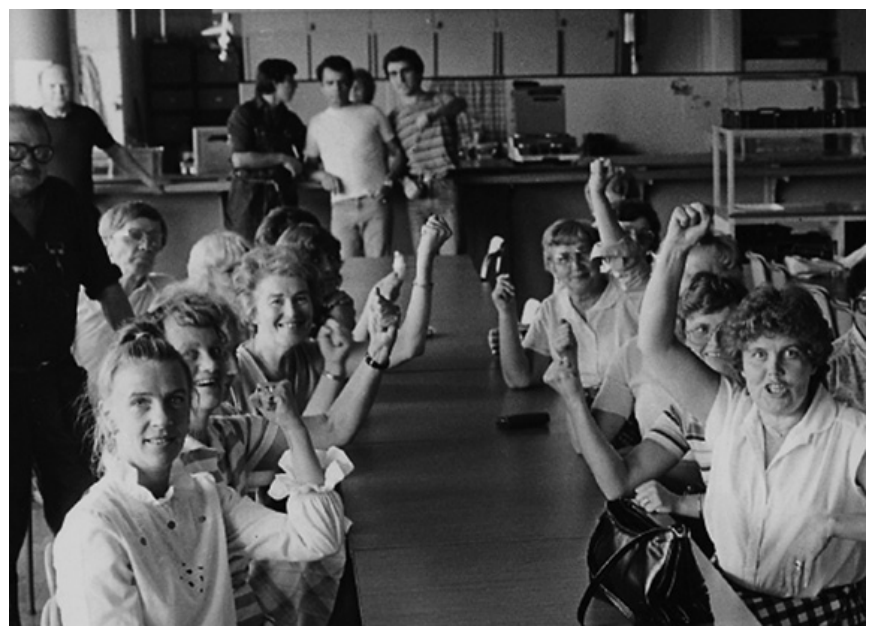

„Läs mer om boken på wrerw.arkiv.nu« 


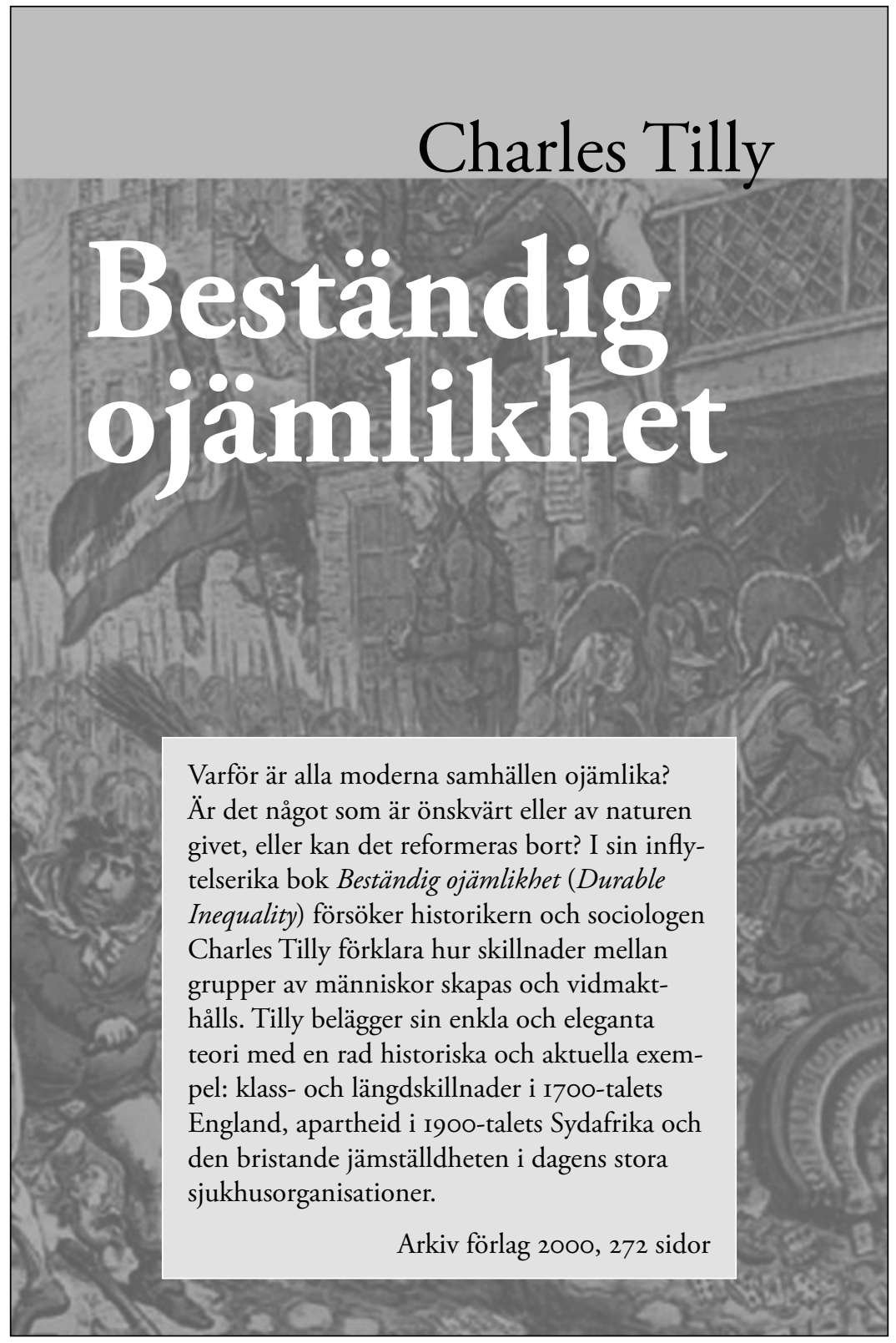

\section{„Läs mer om boken på www.arkiv.nu“}

